\title{
A felismerési kísérlet összehasonlítása más bizonyítási cselekményekkel
}

\section{FENYVESI Csaba ${ }^{10}$}

\begin{abstract}
Minden emberi tevékenység magában hordozza a hibázás lehetőségét. Ez alól a kriminalisták, jogalkalmazók sem kivételek. Jogállamban a legsúlyosabb hibakövetkezmény az úgynevezett "justizmord", "jogi halál", "bírói halál", a téves ítélet, a hibás felelősségre vonás, a nem bünös személy bünösnek nyilvánítása. (Angol terminusai változatosak: miscarriage of justice, wrongful conviction, mistaken conviction, falsely convicted, falsely sentenced, unsafe conviction.) A felismerésre bemutatás elhibázása "justizmord" veszélyü (kiemelten veszélyes vagy "legveszélyesebb" kategória). Ennek megelözése érdekében fontos e bizonyítási metódus vizsgálata, összehasonlítása más bizonyítási cselekményekkel.
\end{abstract}

Kulcsszavak: bizonyítási kísérlet, büntetőeljárás, felismerési kísérlet, helyszíni kihallgatás, justizmord, kihallgatás, kriminalisztika, poligráf, szembesítés, szemle

\section{A felismerésre bemutatás fogalma}

A történeti kutatásokból tudjuk, hogy évszázadokon keresztül a kihallgatás részének tekintették a felismerési eljárást. Szabályozott önállósága a 19. század végén, 20. század elején indult csak el, konkrétan Angliában, majd terjedt el az öreg kontinens országaiban is. Hazánkban a 20. század második részében lett elkülönülten nevesített intézmény. Fogalmát szinte minden tájékon hasonlóan határozzák meg napjainkban. Lényegét tekintve álláspontom szerint olyan önálló igazságkereső (eljárási) cselekmény, amelynek keretében tanúk vagy terheltek büntetőjogilag releváns személyt (holttestet, testrészt, tetoválást, sérülést), állatot, növényt, hangot, tárgyat (iratot, jármúvet), fényképet (videót, filmet, elektronikus felvétel tartalmát), ritkább esetekben szagot, ízt, tapintást, hőt kísérelnek meg helyhez, szituációhoz kötődően vagy nem kötődően kiválasztani, azonosítani.

A hatályos magyar törvényi szabályozás a felismerésre bemutatás elnevezést használja, azonban meglátásom szerint a felismerési kisérlet sokkal inkább helyénvaló lenne. Rövid indokolásom szerint a „felismerésre” és a „bemutatás” szó egyenként

Dr. habil. Fenyvesi Csaba, Pécsi Tudományegyetem Állam- és Jogtudományi Kar Büntető és Polgári Eljárásjogi Tanszék, egyetemi tanár.

Csaba Fenyvesi, PhD, University of Pécs, Faculty of Law, Professor. E-mail: fenyvesi.csaba@ajk.pte.hu 
és együtt is arra sarkallja az egyébként a hatóságnak is sokszor megfelelni kívánó felismerőt, leggyakrabban a bűncselekmény sértett tanúját, hogy a bemutatott személyek (tárgyak, hangok stb.) közül válasszon. Hogy mindenképpen válasszon, hogy mindenképpen valakit felismerjen. A megfelelési kényszer pedig azzal a hibás következménnyel járhat, hogy akkor is választ a felismerő, amikor nem is biztos benne, amikor csak hasonlóságot érzékelt, vagy egyszerűen csak a külső jelekből arra következtet, hogy felismerni véli a valós elkövetőt. Tévedése azonban akár hibás nyomozási verzióhoz és bírósági justizmordhoz is vezethet, mivel a kiválasztását cáfolni elméletileg is nehéz, a gyakorlatban pedig szinte lehetetlen, ha nincs a kiválasztottnak érdemi alibiigazolása. Ezért - a bizonyítási kísérlet mintájára - helyesebb lenne „felismerési kísérlet"-ről beszélni, vagyis a felismerés megkísérléséről, semmint bemutatásról. Ezért szerepeltetem már e kifejezést a tanulmányom címében és a további okfejtésemben is.

Álláspontom szerint a fogalmi tisztázást segíti, ha a felismerési kísérletet elhatároljuk más büntetőeljárási kódexünk (Be.) szerinti bizonyítási cselekményektől, ha megfogalmazzuk a hasonló, ám ugyanakkor eltérő vonásokat is.

\section{A kihallgatás és a felismerési kísérlet}

A fenti bevezetésből is kiviláglik, hogy „szülő-gyermek” kapcsolatról van szó. A kihallgatásból bújt ki a felismerési kísérlet. Nem túlzás azt állítani, hogy egy speciális kihallgatási forma. Hasonló a taktikája, rögzítése, jogorvoslata, a jelenlevők köre (például terhelt védője, tanú ügyvédje, sértett jogi képviselője, fiatalkorú törvényes képviselője), az eseményt vezető hatósági személy, és a célok között itt is szerepel a vallomás (verziók) ellenőrzése, további (új) bizonyíték szerzése. A kihallgatás közbeni tárgyi bizonyíték (fénykép, film, videó) bemutatása, okirat, szakvélemény, terhelt/tanúvallomás felmutatása is mind-mind egyfajta tárgyi vagy reálszembesítés, egyenkénti felismertetés.

A kihallgatást felfoghatjuk a nyomozóval való szembesítésnek is, ${ }^{2}$ az első informális konfrontálódása a terheltnek, tanúnak, sértettnek. A felismerésre bemutatás inkább második körü: szinte mindig a (potenciális) terhelti kihallgatás (nyilatkozat megismerése) után jön el, hiszen akkor már tudjuk, hogy nem ismeri el a bűncselekmény elkövetését.

\footnotetext{
Ez érvényes persze a bírósági kihallgatásra is, ahol a bíró személye a „quasi” szembesülő, egyúttal maga a bíró is tanúvá válik, megfigyeli a kihallgatott személyt, érzékeli, látja, hallja, amit mond. Jerome Frank megfogalmazása szerint: „[L]évén ô is csak egy esendő tanúja annak, ami a tárgyalóteremben folyik.”

„Indianában újra kellett tárgyalni egy ügyet, mert az egyik esküdt látása annyira rossz volt, hogy képtelen volt kivenni az arcokat. Várható, hogy egy napon a bíróságok azt fogják mondani, hogy egy rövidlátó bíró nem vezethet tárgyalást esküdtszék nélkül, csupán hallgatva az elmondottakat, mert nem látja a tanú viselkedését, kifejezéseit, testtartását." Badó Attila (szerk.): Jerome Frank: Bíráskodás az elme itélőszéke előtt. Budapest, Szent István Társulat, 2006. 59-60.
} 
Ám felelősségvállalás esetén sem haszontalan a felismerési kísérlet lefolytatása, mivel alkalmas lehet a hamis beismerés kiszűrésére, illetve a későbbi vallomásváltoztatás, tagadásba átmenés kivédésére, hiteltelenkénti értékelésére.

\section{A helyszíni kihallgatás és a felismerési kísérlet}

Folytathatjuk a „rokonsági sort”, mivel a szintén igazságkereső speciális helyszíni kihallgatási forma is igen közel áll a felismerési kísérlethez, hiszen e körben az aktívan részt vevő (terhelt, sértett, tanú) a bűncselekményhez kötődő helyszínen mutat meg, ismer fel például helyet, tárgyat, eseményt, miközben vallomást tesz.

Hasonlóak a célok is: a vallomás (verzió) ellenőrzése, új bizonyíték szerzése. És mindkettőnél előzetesen el kell mondania az aktív alanynak, hogy miről ismerné fel a helyszínt, tárgyat, illetve a kiválasztandó (általában elkövető) személyt.

A kihallgatott (leggyakrabban a valló terhelt) azonban itt nem személlyel találkozik és nem is detektívtükrön keresztül, hanem a helyszínnel. Mintegy szembesül vele, a helyszín „visszanéz rá”. A felismerési kísérletnél a kiválasztandó személyek üres térbe néznek, nem látják a felismerőt, aki leggyakrabban a szenvedő sértett, nincs „visszanézés”.

$\mathrm{Az}$ amerikai gyakorlatban előfordul olyan, hogy a nyomozó és a gyanúsított elmegy együtt a bűntett pontos helyszínére. A nyomozó nem mond, nem kérdez semmit, csak vár a gyanúsított reakciójára, mondataira. A bűnös gyanúsítottból kiválthatja - ha a gyanúsított még nem egy „megedzett” bűnöző -, hogy esetleg bevallja bűnösségét. Ez a feszültségteremtés kevésbé jellemző a felismerési kísérletre, mivel a tükör mögötti eseményeket nem érzékeli a rejtőzködésben, a sorba belesimulásban, a feszültségmentes állapot mutatásában érdekelt elkövető. A levezető nyomozó sem érdekelt a feszültség növelésében, éppen ellenkezőleg: a legnagyobb nyugalmat kell biztosítania a csendes szemléléshez, a torzmentes választáshoz. A pszichikai nyomás egyébként is csak abban az esetben válhatna be, ha a gyanúsított valóban az elkövető. Semmilyen hatást nem gyakorol egy nem bünös személyre, kivéve, ha megkérdezi: miért hozták el egy másik bűncselekmény tetthelyére?

\section{A szembesítés és a felismerési kísérlet}

A felismeréshez igen közel álló, „ikertestvérnek” is tekinthető a szembesítés, olyanynyira, hogy az angolszász országokban a confrontatio kifejezés alatt a felismertetési processzust értik, miután a kontinentális értelmú szembesítést (az egymás szemébe mondást) nem alkalmazzák igazságkereső módszerként.

Valóban mindkettőben szembeállítás van, azonban gyakorta a felismerő védelme (alkalmanként a nyomozástaktika) érdekében már csak francia (egyirányúan átlátható, „detektív” vagy „velencei”) tükrön keresztül történik ez. Céljában 
és taktikájában is eltérések vannak, hiszen itt a személyazonosítás és nem a vallomás-ellenőrzés áll a középpontban.

A szembesítés lényegét tekintve egy sajátos, „kombinált” kihallgatás, olyan önálló bizonyítási cselekmény, amelynek keretében egyidejűleg két személy kihallgatása megy végbe kifejezetten azzal a céllal, hogy a kihallgatottak korábban tett vallomásai közti lényeges ellentétet feloldják. A felismerés nem vallomások közötti ellentét feloldására törekszik, miközben a gyakorlatban sokszor tagadó (potenciális) terhelt áll a sorban.

Mindkettő speciális kihallgatási kísérletnek fogható fel, amely a múltbéli igazság felkutatására irányul.

Mindkettőt kibújtatták a kihallgatás köpenyéből, és önálló bekezdést kaptak a büntetőeljárási törvényünkben a 20. század végére. Hozzátéve, hogy mindkettő hármas alakzatú intézmény, nemcsak büntetőeljárás-jogi, hanem kriminalisztikai és pszichológiai vetületük is van.

Mindkettőre előzetesen fel kell készülni, el kell végezni az előzetes tájékozódó kihallgatásokat. „Készülj fel az ellenfeledből” - szoktam hirdetni az egyetemi katedráról a joghallgatóknak, a jövendő jurátusoknak (egyúttal ténykutatóknak) is. A felismerési kísérlet előtt feltétlenül meg kell tudni, hogy:

a) miről, milyen személyleírási momentumokról ismerné fel a (leggyakrabban) sértett tanú az elkövetőt;

b) van-e valamilyen viszonya (például ismerőssége) a felismerésben részt vevőkkel;

c) milyen körülmények között (távolság, fény, időjárás stb.) észlelte az elkövetőt.

Mindkettőnél kellő mértékű tér, tágas, jól megvilágított helyiség és folyamatos zavartalanság szükséges a hatékony végrehajtáshoz.

Mindkettő alkalmazható a nyomozás kezdeti, erőteljes „első csapás” krimináltaktikai részeként. ${ }^{3}$

Azonosság az is, hogy mindkettőt a hatóság szakmailag alaposan felkészült, magabiztos tagjának kell irányítania. A végrehajtásnál jelen lehet a terhelt védője és a tanú ügyvédje, a sértett jogi képviselője is.

Mindkettőnél fokozottan ügyelni kell a személyek biztonságára.

Nem kizárt egyiknél sem a süket, néma, illetve süketnéma személyek részvétele. Ez értelemszerú a felismerésnél; a szembesítésnél az a nézetem, hogy a fogyatékosság, a kompenzáló erőteljes gesztikuláció következtében még pszichés előny is lehet. A sértett-tanúval szembesülő terhelt személye esetleg még szánalmat, erőteljesebb sajnálatot érezhet, ami növelheti a lelkiismereti terhet, a közlési vágyat, a megbocsátáskérés iránti szükséget.

Az Erster Angriff vagy first strike lényegéről lásd részletesen a szerző tollából Fenyvesi Csaba: A kriminalisztika tendenciái. Budapest-Pécs, Dialóg Campus, 2014. 
Ugyanez a következtetésem külföldi, a magyar nyelvet nem beszélő személy esetében is. Önmagában a tolmács alkalmazása nem teszi lehetetlenné, értelmetlenné, pszichológiai talaj nélkülivé a szemébe mondás erejét. A felismerés nem is kérdéses esetükben sem.

Egyik formánál sem szabad hallomástanút alkalmazni. Szembesítésnél legfőképpen azon krimináltaktikai okból nem, mert így a tanúnál hiányzik a valódi ténytudásból, tényérzékelésből származó erô és hit, az a többlet, ami nagyon kell az erôteljes, szuggesztív szemébe mondáshoz. Másrészről a hallomástényt a szembesülő személy is észleli, sokkal inkább támadási felületet ad számára, mintsem védekezésre, netán változtatásra (beismerésre) kényszeríti. A felismerési kísérletnél pedig elmondásból, más általi leírásból nem építkezhet, nem választhat ki személyt hitelesen a hallomástanú.

Egyik eset végén sem szabad a végrehajtónak értékelnie az eredményt, és semmilyen módon nem adhat jelzést, sem pozitívat (például dicséretet), sem negatívat (például szemrehányót) a résztvevőknek. Közben és a záráskor sem.

Úgy tűnik azonban, hogy legalább annyi különbséget is fel tudunk sorakoztatni, mint egyezőséget. Ugyanis a felismertetés lehet titkos (rejtett, leplezett) is, a szembesítés sohasem. Az csak nyílt lehet, akár a nyomozási, akár a tárgyalási szakban. Fogalmilag kizárt a titkos szembesítés.

A felismerő (tanú) vonakodása, ellenállása esetén is végrehajtható, kikényszeríthető (legrosszabb esetben fénykép segítségével), míg a szembesítést nem lehet és nem szabad a szembesülő akarata ellenére végrehajtani.

A felismerésnél a múltban rögzült személyképet, emlékképet kell összehasonlítani a felismerő elé táruló valós személyekkel, míg a szembesítésnél fel kell idézni az emlékképeket, azokat aktivizálni (reprodukálni) és közvetíteni is kell.

Mindig több, minimum három személyt mutatunk be az aktív alanynak, szembesítésnél pedig mindig csak egy személy ül vele szemben (összesen ketten lehetnek egymással szemben). Az előbbit többes vagy választásos, az utóbbit egyéni konfrontációnak is nevezhetjük.

Ha a felismerési kísérletnél hibázik a felismerő, végzetes következményei lehetnek, szinte korrigálhatatlan az eljárás során. A tapasztalatok és kutatások szerint a későbbiekben erőteljesen ragaszkodnak a felismerők a hibás döntésükhöz, ami sok esetben justizmordhoz, jogi halálhoz, téves ítélethez vezet(ett). ${ }^{4}$

\footnotetext{
Nagy valószínűséggel ez - a hibalehetőségek miatti fokozottabb érzékenység - a magyarázata annak, hogy a felismerésre bemutatásról jóval szélesebb a (köztük a monografikus) szakirodalom (akár német, akár angol nyelven), mint a szembesítésről. Odenthal ki is emeli monográfiája bevezetőjében: „A gyanúsított téves azonosítása a szemtanú által szembesítéssel vagy fényképes felismeréssel az egyik fő oka a büntetőeljárásban hozott téves ítéleteknek. Seelig megállapítását, miszerint az ismertté vált jogi tévedések nagy száma a téves felismerésen alapul, Peters vizsgálatai a büntetőjog hibaforrásairól is igazolják Ráadásul a megismételt eljárás által korrigált hibás ítéletek száma sem becsülhetô túl nagyra, mert egy tévedésen alapuló rossz azonosítást utólag alig lehet új tények és bizonyítékok segítségével megdönteni. Sok újra felvett eljárásban az ártatlan elítéltet csak a valós tettesi rábizonyítással mentették fel. Angliában ezen hibaforrások miatti nyugtalanság eredményezte a Lord Devlin vezette bizottság bevetését, ami a felismerések eljárási gyakorlatát vizsgálta, és arra az eredményre jutott, hogy az angol büntetőeljárásban a fő hibaforrás a tanúk általi helytelen személyazonosítás." Hans Jörg Odenthal: Die Gegenüberstellung im Strafverfahren. Stuttgart-München-Hannover-Berlin-Weimar, Richard Boorberg, 1992. 19.
} 
Az első felismerést (és ebbe beleértendő az előzetes fényképfelmutatás is) követő megismételt felismerés híján van minden bizonyítási értéknek. ${ }^{5}$ Ezzel szemben a szembesítésnél ilyen eredményű, súlyú hiba, tévedés nem fordulhat elő, amivel nem azt állítom, hogy nem lehet káros, tévútra vivő hatása egy esetlegesen téves, hazug vallomásnak. Ám a bizonyító ereje jóval kisebb.

A felismerésre bemutatás jóval nagyobb munkaigényű előkészületeket kíván, mint a szembesítés, továbbá megismételhetetlen is. Ezenfelül gyakran helyhez, szituációhoz kötődő, ami nem követelmény a szembesítésnél. Sőt kifejezetten hátrányos lehet, ha nem az erre a célra alkalmas, erre készített kihallgatóhelyiségben történik (például büntetés-végrehajtási intézetben, kórházban).

A felismerésnél fontos, hogy a felismerendő személy eredeti, bűncselekménykori állapotának megfelelően jelenjen meg, vegyen részt az eljárásban, mert minden változás, változtatás (haj-, szakáll-, bajuszviselet stb.) megnehezíti, néha ellehetetleníti a cselekményt. A szembesítésnél ilyen követelmény nincs, a személy fizikai, külső változása nem befolyásolja a szemkontaktust.

$\mathrm{Az}$ is fontos elvi tétel, hogy nem helyettesíthetők egymással, azaz nem szabad szembesítés keretében felismerést és felismerés keretében szembesítést tartani. Időrendiségük is jelzi a különbséget, mert tilos szembesítés után felismerésre bemutatást tartani, ám felismerésre bemutatás után engedett a szembesítés alkalmazása.

Gyermekkorú tanúnál tilos a szembesítés, a felismerés megkísérlése viszont nem kizárt. Fiatalkorú, nagyon idős, gyenge idegzetű, túlságosan félszeg tanúknál nem ajánlott a szembesítés, ám a felismerés végrehajtása nem rejt veszélyeket magában, és kisebb a másodlagos viktimizáció esélye is.

Ehhez a gondolathoz kapcsolódik, hogy a sorban álló személyek közül egyik sem lehet az aktív alany ismerőse, míg ez szembesítés esetében nem kizáró tényező.

A szembesítés során az alanyok egymásnak kérdéseket tehetnek fel, a felismerésnél nincs kontaktus az aktív és a passzív alany között.

A szembesítésnél előfordulhat, hogy csak a nyomozás legvégén célszerű taktikai okokból végrehajtani. A felismerések időzítése inkább a kezdetekre esik, hogy minél előbb megerősítse (vagy gyengítse) a személyes (tárgyi) gyanút, a nyomozási irányt.

A nyomozási információk megőrzése vagy a tanú védelme nincs veszélyben a felismerésnél, a szembesítésnél viszont mindkettő csorbát szenvedhet.

A szembesítésnek nagyobb lehet a meglepetésereje és pszichés terhe a (potenciális) terheltre, mint a detektívtükör mögötti (arc és szem nélküli) azonosítás. ${ }^{6}$

Nincs igazán meglepetésereje és pszichés nyomást adó szerepe a videóláncolaton (online módon) keresztül végzett szembesítésnek, ugyanakkor nem kizárt a felismerés, a kiválasztás megkísérlése e technikai áttétellel.

Az eredménytelen szembesítésnél teljesen elegendő a jelentésbeli rögzítés, a felismertetésnél azonban mindig részletes, pontos jegyzőkönyv szükséges. Hozzáteszem,

Ezen anomáliáról részletesen értekezett tanulmányában Katona Géza: Még egyszer Magda János bünügyéről. Belügyi Szemle, 24. (1986), 8. 94-110.

6 Lásd erről még Tóth Mihály: Feloldható-e a béklyó? Jogtudományi Közlöny, 39. (1984), 5. 286. 
hogy különösen akkor, ha (részben) funkcionális tulajdonságok alapján (például járás, beszéd, hang) történik a személykiválasztás. Célszerủ még a jegyzőkönyv mellékletét képező fényképezésen túlmenően sokkal modernebb technikai eszközöket (például videót, digitális kamerát) alkalmazni.

Ha tagadásból beismerésbe hajlott át a szembesülő terhelt, akkor azonnal a szembesítést követően részletes tettestudomású folytatólagos vallomást kell felvenni, ami később - alappal - megváltoztathatatlan. Ekkor ki kell térni a beismerés motívumaira is, nem csak a ténykérdésekre. A kihallgatás lehet helyszíni kihallgatás (vagy bizonyítási kísérlet) keretében is, ahol a beismerésben levő terhelt még „melegében” megmutatja az útvonalakat, helyszínt, a történéseket, az események sorrendjét, az olyan tényeket és bizonyítékokat (eszközt, zsákmányt stb.), amelyeket csak az az ember ismerhet, és olyan mélységben, aki valóban elkövette a cselekményt. Ha a tanú/sértett határozottan felismerte az elkövetôt, akkor a pontos felismerési jegyzőkönyv után nem kell feltétlenül folytatólagos kihallgatást foganatosítani vagy egyéb nyomozási cselekményeket végrehajtani. Kellő bizonyító ereje lehet magának a jegyzőkönyv tartalmának (a fényképes-videós mellékletekkel együtt).

\section{A bizonyítási és a felismerési kísérlet}

A bizonyítási kísérlet lényegét egy irodalmi példával kívánom kezdésként bemutatni.

A havasalji nemzetközi cserkésztáborban történt az eset 1913. július 21-én. Hat különböző nemzetiségú, vallású tizenéves fiú elkötötte a vén Hiribi fadöntő csiribóki égerek közé bújtatott ladikját. A sovány fájú egyetlen evező azonban gyorsan megadta magát, és a magatehetetlen csónak iszonyú sebességgel vágtatott a folyón lefelé, a zúgó felé. A vízesés mélységes, dübörgő torkánál, „szinte már a következő pillanatban alá kellett volna zuhanjon a mélységbe [...] és akkor hirtelen megállt. Megállt a harsogó víztömeg közepén, mintha megakadt volna valamiben. És állt mozdulatlanul. A fadöntő kiáltozására felrohantak a tutajosok a gát alól és kimentették a hat gyereket. Nem ment gyorsan a mentés, beletelt egy óra is, de a csónak állt mozdulatlanul, csak remegett minden deszkája a víz erejétől. Hanem abban a pillanatban, amikor az utolsó gyerek is kimászott belőle a fölötte átdobott kötélen: megrázkódott, elejével a magasba emelkedett és alázuhant a mélységbe. Forgáccsá ment szét a sziklákon. De a gyerekek akkor már biztonságban voltak"?

Egy korábbi személyes tragédia (fia tragikus halála) miatt nem istenhívő Hiribi a megrázó eseményt követően ellenőrizte a zúgót, és megállapította, hogy a toroknál, a vízesés kezdetén, ahol a csónak megakadt, nincs semmi természetes (például rönk, faág, zátony, szikla) vagy mesterséges (gát, halászfa, cölöp) akadály, ami fenntarthatta, meggátolhatta a mélybe zuhanást, a továbbhaladást. Ha pedig

Wass Albert: Elvész a nyom. Pomáz, Kráter, 2003. 5. 
nincsen, akkor valami külső, emberfeletti, mondjuk ki, isteni erő lehet a háttérben, ami megmentette a fél tucat meggondolatlan serdüló életét.

Ezen morfondírozott napokon keresztül, mígnem arra jutott, hogy a kételyeit, hogy létezik-e Isten, aki megmentette a zöldinges gyerekeket, ellenőrizni kell. Bizonyosságot akart szerezni a magasabb rendủ létezéséről. Logikája szerint, ha ő is elindul egy másik, ugyanolyan ladikkal, megfigyelheti: vajon az övét is megakasztja-e valami a végpont előtt? Ha igen, akkor van valami ott, ami így tesz, csak nem látja, nem érzékeli, például a sekélység (a véletlen), és akkor nem kellett mennyei beavatkozás. Ha nem állítja meg semmi, akkor igenis a bután vakmerő tizenéves fiúkat az Isten segítette, s fogta vissza a pusztulástól. És éppen olyan módon és csak annyi időre, amíg kötéllel, egyesével kihúzták őket a partra a sebes folyó környékén dolgozó fadöntők.

Gondolatát tett követte. A falu népe által szolidaritásból kárpótlásként öszszeadott, a korábbival megegyező méretű, formájú csónakjának első útja a zúgó felé vezetett. Ebben hat ifjú helyett már csak ő maga ült, de megtöltött öt zsákot kővel 40-50 kilósra, és egyenként beemelte maga mellé őket. Pontban akkor indult, mint a fiatalok, és pont olyan verőfényes nyári napsütésben. A folyó sem volt más, ugyanúgy zsongott, rohant, mint pár napja, azon az inkriminált fiatalos hétköznapon. Evezőt ő sem használt már a malomtó közepétől. Eldobta jó messzire, ott, ahol a folyó sodrása elindult. Csak ült a padon, és figyelte a csónak elragadását, a gát felé rohanás egyre fokozódó sebességét. „Mikor odaért, pontosan arra a helyre, ahol annak idején a gyermekek csónakja csodálatosképpen megakadt volt, akkor felállt az öreg Hiribi a vadonatúj csónakban. Akik látták, esküdtek rá, hogy olyan volt az arca, mint az apostoloknak. Még akkor is énekelt, amikor a csónak átfordult vele a zúgón. Belekerült jó néhány órába, amíg a holttestét ki tudták horgászni lent a tutajosok. A szép új csónak is pozdorjává tört. Biztos mondták az emberek, hogy eszét vesztette az öreg Hiribi és úgy ment a halálba."8

Az eleddig nem istenhívő ember a zuhanás pillanatában, az átbukás után kisimult arccal jött rá és nyugodott meg, hogy létezik számára Isten, hiszen Ô menthette meg a fiatalokat. Nekik járt ez a kegy, de nem bánta. Elérte a bizonyosságot, és ez elégtétel volt számára. Énekelve bukott sírjába.

Véleményem szerint a sokat tapasztalt Hiribi egyáltalán nem volt bolond. Egyszerűen csak elvégzett egy kriminalisztikai és büntetőeljárás-jogi értelemben vett bizonyítási kísérletet. Igyekezett mindenben a krimináltaktikai előírásoknak megfelelően eljárni. Vagyis az eredeti kriminális szituáció tökéletes modellezését, lemásolását igyekezett elérni. Nevezetesen:

a) ugyanolyan méretű, formájú, lakkozású, festésű csónakot használt;

b) ugyanakkor indította a kísérletet, mint amikor az inkriminált cselekmény történt;

c) az időjárási körülmények megegyeztek a pár nappal előttivel;

\footnotetext{
Wass (2003): i. m. 25.
} 
d) a folyó ugyanolyan jellemzőket mutatott, mint a fiatalok siklása idején;

e) hasonló súllyal és elosztással terhelte (mesterségesen beállítva) a csónakot, mint a hat cserkészgyermek;

f) ugyanott rohant a gát felé, mint az első csónak;

g) ugyanúgy nem használt evezőt, amikor a malomtóból áttért a folyóra, amikor megkezdődött a sodrás (ahogyan a serdülőknél is történt).

A hét fő kriminalisztikai kérdés (mi? hol? mikor? hogyan? ki? kivel? miért?) közül a motivációra utaló miértnél más a válasz a korábbihoz képest, ez azonban irreleváns a bizonyítási kísérlet esetében. Ahogyan az intézmény találó neve is mutatja, „kísérlet”-ről van szó, amelynek bizonyíték-ellenőrzési funkciója van. Hiribi akciója is ezt a célt szolgálta. Bizonyosságot szeretett volna kapni. A kriminalisták is ezt szeretnék: megtudni, hogy valami történhetett-e úgy, ahogy a verzió szerint felállították, ahogyan a terhelt vagy netán a sértett, a tanú elmondja. Hiribinél hitkérdés ellenőrzése folyt, a kriminalistáknál a verzió is valamiféle hitre, ám nem istenhitre, hanem alapadatokra, meglévő információkra épül. Ám nem túlzás kimondani, hogy a hatóság (a terhelt, a sértett, a tanú) azt hiszi, hogy valami úgy történt, ahogyan a verziójukban szerepel. Ezt a hitet, gondolatot, sejtést, verziót (részverziót), alkalmanként vallomási védekezést, sértetti-tanúi állítást kell megerősíteni vagy elvetni. A kísérlet járhat új bizonyíték szerzésével is, amely fokozhatja vagy gyengítheti a pró és kontra érveket, és útmutatást adhat új, más verziók felállításához is.

A vallomás igazságtartalmának ellenőrzésére szolgáló bizonyítási kísérlet egyfajta szembesülés a valósággal az azon részt vevő, korábban vallomást tett személy (akár terhelt, akár sértett-tanú) esetében. A bizonyítás elméletileg értékesebb: a negatív, kizárt eredményt hozó bizonyítási kísérlet önmagában alkalmas lehet olyan hatások kiváltására, amely vallomás változtatást idéz elő a részt vevő személyben. Szembesül a személy a kísérlet során, hogy állítása tarthatatlan, az nem felel meg a valóságnak, az eljárás során feltárt bizonyítéknak. Ám hangsúlyozom, ez a negatív, lezáró-kizáró eredményű bizonyítási kísérletnél működhet, a pozitív esetében, a lehetőségi eredménynél ilyen eredmény nem várható, nem jön létre a valóság és a vallomás közötti ellentét.

Az irodalmi levezetésből is kitetszik már a bizonyítási cselekményekről, hogy:

a) mindkettőnél igazságkeresési kísérletről van szó;

b) mindkettőnél azt reméli a hatóság, hogy választ kap arra, hogy történhetett (vagy nem történhetett) valami, illetve ki lehetett (vagy nem lehetett) a tettes;

c) nem folytatható olyan bizonyítási kísérlet (de felismerési kísérlet sem), amely életveszélyes, ami sértheti az egészséget és az emberi méltóságot, szemérmet;

d) a felismerési kísérlet sikeréről akkor beszélhetünk igazán, ha pontos, valóságos kiválasztás (tehát pozitív fordulat) történik, a bizonyítási kísérletnél ez a kevésbé értékes, inkább a kizáró (a negatív) végeredményű a nyomozást előrébb vivő; 
e) a bizonyítási kísérletnél sokkal több a torzító tényező, mint a nem szituációhoz kötött felismerési kísérletnél (nem ugyanazon időben, napszakban, órában végzik a bizonyítási kísérletet; nem ugyanazon személyekkel, súlyban, érzékszervi különbségekkel rendelkezőkkel hajtják végre); eltérőek az időtartam-, fény-, látási, talaj-, út-, víz-, légköri, csapadék-, sebesség-, forgalmi, zaj-, zavar-, tömegviszonyok; nem az érintett eszközökkel, nem ugyanazon gépjármúvel, munkaeszközzel, ruházattal, robbanószerrel, fegyverrel modelleznek. $^{9}$

Elvi éllel mondható ki, hogy mindkét bizonyítási kísérleti eredmény, vagyis a pozitív és a negatív is közvetett bizonyítékként használható fel. Ha ugyanis a negatív eredményt közvetlen bizonyítéknak tekintjük, akkor az rendszerint közvetlen mentő bizonyíték is lenne. Ez pedig távolról sincs így. Például a terhelttől lefoglalt álkulccsal nem lehet kinyitni a kifosztott lakás ajtaját; ez a negatív eredmény lényegében csak azt jelenti, hogy egy lehetséges verzióval és egy lehetséges közvetett bizonyítékkal kevesebb áll rendelkezésre. (Még inkább ilyen összefüggés van az észlelhetőséget tisztázó bizonyítási kísérletnél. Ha a tanú nem láthatta, vagy nem hallhatta a terheltet, ez önmagában nem zárja ki a terhelt jelenlétét, illetve bűnösségét.) A terheltnek ugyanis lehet még más álkulcsa, nem is szólva arról, hogy esetleg álkulcs nélkül (lopott vagy másolt kulccsal stb.) is elkövethette a büntetendő cselekményt. Közvetlen mentő bizonyíték elfogadása esetén bizonyossággal kizárt, hogy a terhelt az elkövető. ${ }^{10}$ Más kérdés, hogy a folyamatban levő ügyben közvetett bizonyítékként nagyobb bizonyító ereje lehet a bizonyítási kísérlet negatív eredményének, mint a pozitívnak. ${ }^{11}$ (Ahogyan erre fentebb már utaltam.) Úgy is fogalmazhatok sommásan, hogy a bizonyítási kísérlet eredménye ritkán perdöntő, különösen, ha lehetőségi modellt mutat. A felismerési kísérlet sértettjének (cselekményi szemtanújának) személykiválasztása viszont kifejezetten súlyos, közvetlen terhelő bizonyítékként, Damoklész kardjaként lóghat a kiválasztott terhelt feje felett, és a végső bírósági mérlegelésnél is erôsen nyomhat a latban.

Mindkettőnél a hatóságnak (az irányító személynek) törekedni kell az eredeti szituáció visszaállítására, ha helyhez kötött (rekonstrukciót igénylő) cselekményekről van szó.

A jelenségek észlelhetőségének bizonyítási kísérlettel ellenőrzése (például láthatóságának, hallhatóságának vagy más módon való érzékelhetőségének, igen ritkán:

$9 \quad$ Ez azonban csak megközelítő lehet minden esetben. A tökéletes megismételhetőség sokkal inkább teoretikus vágyálom, mintsem realitás. Ezt az elvi tételt mindig be kell kalkulálnia a bizonyítékot értékelő hatóságoknak, végső soron a bíróságoknak a mérlegelő tevékenységük során.

10 Részletesebb kifejtését lásd Tremmel Flórián: Bizonyítékok a büntetóeljárásban. Budapest-Pécs, Dialóg Campus, 2006. 141-154, illetve: Tremmel Flórián - Fenyvesi Csaba - Herke Csongor: Kriminalisztika. Tankönyv és atlasz. Budapest-Pécs, Dialóg Campus, 2005. 321.

11 Lásd erről részletesebben Budaházi Árpád: Bizonyítási kísérlet a felderítésben és a bizonyításban. In Gaál Gyula - Hautzinger Zoltán (szerk.): Modernkori veszélyek rendészeti aspektusai. Pécs, Magyar Hadtudományi Társaság Határőr Szakosztály Pécsi Szakcsoport, 2015. 127-132. 
szaglás, ízlelés, tapintás, ingerküszöb tisztázása) tartalmában erősen hasonlít a felismerési kísérlethez. Gondoljunk csak arra, hogy veleszületett adottság vagy begyakorlottság folytán hihetetlenül finom hallási, látási képesség alakulhat ki az emberben. Például az autószerelő a motor hangja alapján ismeri fel a hibát, illetőleg az adott gépkocsit. ${ }^{12}$

Ha a gyanúsított nem kíván részt venni vagy aktívan közremúködni (illetőleg azt csak tetteti) a bizonyítási kísérleten, akkor dublőr vehető igénybe. A helyettesítőnek hasonló alkatúnak, korúnak kell lennie, mint a terheltnek. ${ }^{13}$ Felismerési kísérletnél nem szabad passzív alanyt helyettesítő dublőrt állítani a sorba.

A terhelt védője, a tanú ügyvédje, a sértett jogi képviselője mindkettőn jelen lehet, és gyakorolhatják törvényes jogaikat.

Kívánatos mindkettőnél a fényképes, videós, elektronikus rögzítés, a későbbi (például bíróság általi) visszanézés lehetőségének biztosítására.

\section{A szemle és a felismerési kísérlet}

Tekintettel arra, hogy mind a szemle, mind a felismerési kísérlet körében a nyomozási szakon látom a hangsúlyos szerepet, így a nyomozási helyszínen folytatott szemlére fókuszálom az összehasonlítást. Ennek körében távolibbnak tűnik a kapcsolat, mint az előzőeknél.

Előfordulhat, hogy személy-, tárgy-, hangfelismerést az eredeti helyszínen (szituációhoz, területhez, ottani fényviszonyokhoz kötötten) célszerű elvégezni.

Időben a felismerési kísérlet mindig későbbi, hiszen a szemle leggyakrabban (halaszthatatlan, azonnali) kezdeti nyomozási cselekmény. Olyankor nincs még látóképben potenciális elkövető sem, így sorba állítható személy sincs általában. Pont a helyszíni adatokból, nyomokból, anyagmaradványokból lehet majd „in personam” gyanú és lehetőség kiválasztásos felismerési kísérletre.

Helyszínen tetten ért elkövetőnél is előfordulhat felismertetés, ha netán előtte látta más tanú, például valamely előcselekményénél.

Olyan is előfordult már a gyakorlatban, hogy a felismerő sértett (tanú) a helyszínen észlelte, ismerte fel, hogy nem is ott látta az elkövetőt, a felismerendő személyt.

A szemle eredménye is kiválthat más igazságot, más vallomást az addig kihallgatott felismerő tanúból. A szemleadatok mutathatják, hogy nem is láthatta olyan távolságból, pozícióból a kiválasztandó vagy már kiválasztott személyt, tárgyat, illetve nem hallhatta (például épületakadályok miatt) a leírt hangot.

12 Gyakorlati esetként említem meg, hogy a szolnoki, kisgyermek sérelmére elkövetett - Magda János elleni - ügyben bizonyítási kísérlettel ellenőrizték, hogy vajon a tanú láthatta-e az általa megjelölt távolságból a terhelt arcvonását, őt felismerhette-e. Kiderült, hogy nem láthatta pontosan. Lásd erről részletesebben Katona (1986): i. m. 96-104.

13 Például a Magda János elleni, már idézett emberölési nyomozásban a terhelt csak tettette a holttest elrejtését szolgáló sírkő megemelését, míg a hasonló felépítésű dublőr ezt meg tudta tenni. Ennek azonban nagyon csekély bizonyító értéke volt. 
Mindkettőnél lényeges, hogy megismételhetetlenek, visszafordíthatatlanok - felismerésnél ugyanazon személyek (azonosító - azonosított) között. Ha egyszer megtörtént a szemle, újra „nem nyílik meg a könyv, amiből olvasni kell tudni” elsőre, a felismerésben pedig befolyásolásnak minősülne egy ismétléses másik alkalom.

A felismerésekhez nem kell speciális tudású szakértő, szemléken viszont gyakran szükség van rá. (Például orvos-, fegyver-, műszaki szakértő.)

\section{Múszeres vallomásellenörzés (poligráf) és a felismerési kísérlet}

A poligráf és a hozzá hasonló műszerek és technikák, csakúgy, mint a felismerési kísérlet igazságkereső, vallomás-ellenőrző, felderítő eszközök. Ha a kihallgatás a „szülője” a felismerésnek, akkor a poligráf a „testvére”, mivel itt is speciális kihallgatásról van szó, amely során őszinteség-ellenőrzés folyik. ${ }^{14}$

Felismerésnél a tanú (sértett) együttmúködésre kötelezett, nem tagadhatja meg azt, mint a poligráfnál, és ennek a kikényszeríthetőségnek a krimináltaktikai követelmények sem mondanak ellent. ${ }^{15}$

A közremúködést megtagadó gyanúsított sem lehet alany a poligráfnál, a felismerési sorba azonban beállítható, azt tűrni köteles. Más kérdés, hogy folyamatos rendzavarása, a végrehajtás fizikai lehetetlenné tétele esetén a fényképét célszerü inkább bemutatni.

Szaktanácsadó besegíthet a műszeres ellenőrzésnél, a felismerési kísérlethez nincs szükség ilyen támogatóra.

A poligráf csak nyomozási szakban használható, a felismerés azonban a bírósági-tárgyalási szakban is bizonyítási eszköz lehet a törvény szerint. Hozzáteszem, hogy akkor a súlya elenyésző, és nincs sok köze a végrehajtásnak a kriminalisztikai ajánlásokhoz.

A nyomozási felismerési kísérlet eredménye „veszélyesebb” lehet, mint a poligráfé. ${ }^{16}$ Perdöntővé válhat, miközben pusztán a poligráfos terhelés alapján nem ítélhető el a terhelt, a módszer elméleti és gyakorlati bizonytalanságai miatt. ${ }^{17}$

Fiatalkorú és gyermekkorú sem vizsgálható poligráffal, miközben lehetnek felismerő személyek, és a (büntethető) fiatalkorú szerepelhet az azonosítandók között is.

14 Lásd erről részletesebben Hautzinger Zoltán: Az igazságügyi őszinteségvizsgálat. In Korinek László - Kőhalmi László - Herke Csongor (szerk.): Emlékkönyv Irk Albert egyetemi tanár születésének 120. évfordulójára. Pécs, Pécsi Tudományegyetem Állam- és Jogtudományi Kar, 2004. 43-52.

15 Finszter Géza megfogalmazásában: „A bűnügy feltárásának mindig sajátos arculatot ad - és ezért a jogi megismerés más területeivel nem rokonítható - a bủn rejtôzködő természete, valamint a büntetőhatalom legitim erőszak monopóliuma." Lásd részletesebben Finszter Géza: Bizonyításelméletek a jog világában. Rendészeti Szemle, 54. (2006), 7-8. 79.

16 Lásd erről részletesebben Fenyvesi Csaba: A justizmordhoz vezető kriminalisztikai hibák. Belügyi Szemle, 62. (2014), 3. 30-59.

17 A poligráfos vizsgálatok validitásáról részletesebben olvasható Budaházi Árpád: Poligráf. Müszeres vallomásellenôrzés bünügyekben. Budapest, NKE Szolgáltató Kft., 2014. című monográfiájában. 


\section{Zárógondolat}

Abban reménykedhetünk, hogy a felsorolt bizonyítási cselekmények, köztük kiemelten a „fokozattan veszélyes következményű” felismerési kísérlet jövőbeli jogszerű és szakszerű hatósági végrehajtása eredményeként elkerüljük, kivédjük, megelőzzük a tévedéseket, a hibás ítéleteket, végső soron az emberi sorsokat tragikusan érintő justizmord eseteket.

\section{FELHASZNÁLT IRODALOM}

Badó Attila (szerk.): Jerome Frank: Bíráskodás az elme itélőszéke elött. Budapest, Szent István Társulat, 2006.

Budaházi Árpád: Poligráf. Müszeres vallomásellenörzés bünügyekben. Budapest, NKE Szolgáltató Kft., 2014.

Budaházi Árpád: Bizonyítási kísérlet a felderítésben és a bizonyításban. In Gaál Gyula - Hautzinger Zoltán (szerk.): Modernkori veszélyek rendészeti aspektusai. Pécs, Magyar Hadtudományi Társaság Határőr Szakosztály Pécsi Szakcsoport, 2015. 127-132.

Fenyvesi Csaba: A justizmordhoz vezető kriminalisztikai hibák. Belügyi Szemle, 62. (2014), 3. 30 59.

Fenyvesi Csaba: A kriminalisztika tendenciái. Budapest-Pécs, Dialóg Campus, 2014.

Finszter Géza: Bizonyításelméletek a jog világában. Rendészeti Szemle, 54. (2006), 7-8. 70-102.

Hautzinger Zoltán: Az igazságügyi őszinteségvizsgálat. In Korinek László - Kőhalmi László - Herke Csongor (szerk.): Emlékkönyv Irk Albert egyetemi tanár születésének 120. évfordulójára. Pécs, Pécsi Tudományegyetem Állam- és Jogtudományi Kar, 2004. 43-52.

Katona Géza: Még egyszer Magda János bünügyéről. Belügyi Szemle, 24. (1986), 8. 96-104.

Odenthal, Hans-Jörg: Die Gegenüberstellung im Strafverfahren. Stuttgart-München-HannoverBerlin-Weimar, Richard Boorberg, 1992.

Tóth Mihály: Feloldható-e a béklyó? Jogtudományi Közlöny, 39. (1984), 5. 282-287.

Tremmel Flórián: Bizonyítékok a büntetőeljárásban. Budapest-Pécs, Dialóg Campus, 2006.

Tremmel Flórián - Fenyvesi Csaba - Herke Csongor: Kriminalisztika. Tankönyv és atlasz. BudapestPécs, Dialóg Campus, 2005.

Wass Albert: Elvész a nyom. Pomáz, Kráter, 2003.

\section{ABSTRACT}

\section{Comparison of the Recognition Attempt with Other Acts of Proof}

\section{Csaba FENYVESI}

Every human activity carries with it a possibility of error. Criminalists and the appliers of law are no exception to this rule. In a state governed by the rule of law, the most serious consequence is the 'justizmord' ('legal death', 'judicial death' or 'judicial murder'), which means erroneous judgment, holding a person criminally responsible mistakenly, finding the not guilty person guilty in court. (There is a great variety of English terms for it: 'miscarriage of justice', 'wrongful conviction', 'mistaken conviction', 'falsely convicted', 'falsely sentenced' 
and 'unsafe conviction'.) The mistakes of a recognition attempt (lineup) are carrying the danger of 'miscarriage of justice' (highly dangerous or the 'most dangerous' category). Therefore, in order to prevent this, it is important to examine this method of proof and compare it with other acts of proof.

Keywords: crime reconstruction, criminal procedure, identity attempt, interrogation, interview, crime scene interrogation, miscarriage of justice, criminalistics, polygraph, confrontation, crime scene investigation 